\title{
WYDATKI BUDŻETOWE SAMORZĄDÓW TERYTORIALNYCH JAKO DETERMINANTA ROZWOJU SPOLECZNO- -GOSPODARCZEGO POLSKICH WOJEWÓDZTW
}

\section{Wstęp}

Realizacja celów państwa wiążę się z koniecznością posiadania środków finansowych. Dla wykonania postawionych zadań, konstruowany jest budżet państwa. Głównym źródłem dochodu budżetu są podatki. Podatki są to świadczenia obywateli na rzecz państwa określone przepisami prawnymi. W związku z tym, że podatki są najważniejszą determinantą wzrostu dochodu narodowego, znacząco wpływają na funkcjonowanie całej gospodarki. Co więcej, za pomocą stopy podatkowej rząd może regulować strukturę gospodarki, na przykład poprzez przyspieszenie lub wyhamowanie działań inwestycyjnych w pewnych gałęziach przemysłu na poszczególnych obszarach kraju.

Największym dylematem polityki fiskalnej państwa jest odpowiedni podział dochodu narodowego. Racjonalna i uzasadniona ekonomicznie struktura wydatków, możne zapewnić stały wzrost społeczno-gospodarczy. Ogólnie rzecz biorąc wydatki budżetowe można podzielić na dwie podstawowe grupy:

1. Wydatki na wszelkiego rodzaju dobra i usługi konsumpcyjne oraz inwestycje publiczne.

2. Budżetowe transfery, takie jak: emerytury, renty i zasiłki, dotacje i subwencje etc.

Wydatki budżetowe działają jak automatyczny stabilizator, napędzając tym samym aktywność sektora przedsiębiorstw. Całość pozytywnie wpływa na poziom dochodu narodowego oraz poziom zatrudnienia. Jak można zaobserwować w większości wysoko rozwiniętych państw, polityka fiskalna opiera się na znacznym udziale wydatków budżetowych. Wówczas z reguły dochodzi do takiej sytuacji, że wydatki przewyższają dochody, w konsekwencji powstaje deficyt budżetowy. Celem autorów artykułu jest wskazanie siły wpływu wydatków budżetowych samorządów terytorialnych na wzrost społeczno-gospodarczy we wszystkich polskich województwach, dzięki czemu będzie można wyciągnąć wnioski, w których obszarach struktura wydatków budżetowych jest poprawna, a w których wymaga niezbędnego udoskonalenia.

\footnotetext{
* Doktorantka, Zakład Logistyki, Wydział Ekonomiczno-Socjologiczny UŁ.

** Doktorant, Katedra Ekonometrii Przestrzennej, Wydział Ekonomiczno-Socjologiczny UŁ.
} 


\section{Definicja i funkcje budżetu państwa}

Pojęciem budżetu państwa określa się centralny plan finansowy, który jest podstawą prowadzenia gospodarki finansowej uwzględniającej politykę społeczną, gospodarczą i obronną. Budżet obejmuje szczegółowy bilans dochodów i wydatków władz i organów oraz administracji rządowej. Uchwalany jest corocznie przez Sejm na okres jednego roku budżetowego w formie ustawy budżetowej ${ }^{1}$.

Bardzo istotne dla konstrukcji, uchwalania i wykonywania planu budżetowego są zasady budżetowe. Należy uznać je za trwałe cechy szczególne, związane z sensem istnienia budżetu. Często wątpliwości związane z zasadami budżetowymi budzi ich liczba. Niektórzy naukowcy wymieniają ich kilka, z kolei inni kilkanaście ${ }^{2}$. Zasady budżetowe określają treść i strukturę budżetu, ale również całą procedurę budżetową. Zasady te mogą mieć charakter normatywny, czyli mogą być ujęte w formie przepisów prawnych. Najistotniejsze zasady budżetowe to przede wszystkim:

- zasada zupełności - narzuca konieczność uwzględnienia w budżecie wszystkich dochodów i wydatków państwa jakie są planowane w najbliższym roku budżetowym;

- zasada równowagi - wymaga zachowania odpowiedniej proporcji pomiędzy dochodami a wydatkami, w praktyce zasada ta jest niezwykle trudna do zrealizowania, dlatego też bardzo często władze stosują politykę deficytu budżetowego);

- zasada jedności - budżet powinien stanowić jedną całość organizacyjno-prawną i powinien być wyrażony poprzez jeden akt prawny;

- zasada szczegółowości - plan budżetowy musi być szczegółowo uporządkowany (podzielony na części, działy, rozdziały i paragrafy) oraz usystematyzowany - zasada ta odnosi się zarówno do aspektów ekonomicznych, jak i politycznych;

- zasada specjalizacji - wydatki budżetowe powinny być przeznaczone na szczegółowo wcześniej określone cele;

- zasada jawności - cała gospodarka finansowa musi być ogólnodostępna, wymóg ten jest spełniany poprzez: jawność debaty budżetowej, opublikowanie ustawy budżetowej i wykazu kwot udzielonych dotacji oraz publikacji danych dotyczących długu publicznego;

- zasada uprzedniości - budżet należy uchwalić do końca roku poprzedzającego rok budżetowy, istnieją odstępstwa od tej zasady uwzględnione

${ }^{1}$ B. Brzeziński, T. Dębowska-Romanowska, M. Kalinowski, W. Wójtowicz, Prawo finansowe, C.H. BECK, Warszawa 2000, s. 71.

${ }^{2}$ A. Borodo, B. Brzeziński, E. Drgas, J. Głuchowski, J. Jezierski, Zarys prawa finansowego, Wyd. UMK, Toruń 1989, s.30. 
w przepisach o terminach uchwalania budżetu, które wskazują również konsekwencje dla władzy, gdy budżet nie zostanie uchwalony w odpowiednim czasie;

- zasada roczności - budżet uchwala się na rok kalendarzowy, regulacje prawne przewidują również składowe wieloletniego planowania finansowego, np.: w zakresie działań inwestycyjnych, ale te zagadnienia są zapisane w odrębnych przepisach prawnych ${ }^{3}$.

Omawiając klasyfikację zagadnienia polityki budżetowej można wymienić trzy podstawowe funkcje budżetu: fiskalna, redystrybucyjna oraz stymulacyjna. Często wyróżnia się także jako czwartą funkcję budżetu państwa: funkcję alokacyjną, która ma za zadanie podział czynników produkcji.

Funkcja fiskalna polega na gromadzeniu dochodów budżetowych, które w głównej mierze pochodzą z pozyskiwanych podatków, co ma umożliwić utrzymanie aparatu państwowego oraz realizację określonych zadañ ${ }^{4}$.

Funkcja redystrybucyjna polega na niwelowaniu dysproporcji rozwojowych poszczególnych regionów poprzez odpowiedni podział dochodu narodowego. Dzięki tego typu działaniom zmniejsza się dysproporcję dochodów różnych grup społecznych oraz zapewnia się bezpieczeństwo socjalne dla najuboższych. Funkcja ta realizowana jest poprzez system podatkowy (na przykład ulgi i zwolnienia podatkowe) oraz wydatki budżetowe (na przykład emerytury, renty i zasiłki).

Funkcja stabilizacyjna odnosi się do wpływu dochodów i wydatków na życie gospodarcze i społeczne. Ma ona zapewnić osiągnięcie celów gospodarczych w wymiarze mikroekonomicznym. Funkcja ta uważana jest za najistotniejszą funkcję polityki budżetowej, ponieważ poprzez poziom zagregowanego popytu można kształtować stabilny poziom cen, wysokie zatrudnienie oraz równowagę zewnętrzną, a w konsekwencji wzrost gospodarczy ${ }^{6}$.

Funkcja alokacyjna polega na rozdysponowaniu czynników produkcji poprzez finansowanie inwestycji publicznych. Dzięki takim działaniom w pewien sposób można wyrównać niedoskonałości mechanizmu rynkowego i zapewnić wszystkim możliwość korzystania z niezbędnych dóbr i usług. Należy również podkreślić, że poprzez odpowiedni podział zadań pomiędzy sektor publiczny i prywatny, można wpłynąć na podniesienie efektywności inwestycyjnej. Reasumując, usługi publiczne można podzielić na dwie grupy: konieczne i pożądane. Pierwszą grupę stanowią usługi świadczone tylko i wyłącznie przez sektor publiczny w sposób nieodpłatny (administracja, obrona narodowa, sądownictwo etc.). W drugiej grupie znajdują się między innymi oświata i ochrona zdrowia (te usługi mogą być świadczone również przez podmioty

\footnotetext{
${ }^{3}$ A. Borodo, Polskie prawo finansowe. Zarys ogólny, Dom Organizatora, Torun 2003, s. 51-54.

${ }^{4}$ R. Milewski, E. Kwiatkowski (red.), Podstawy ekonomii, Wyd. Nauk. PWN, Warszawa 2008, s. 310.

${ }^{5}$ Ibidem.

${ }^{6}$ B. Winiarski (red.), Polityka budżetowa, Wyd. Nauk. PWN, Warszawa 2006, s. 289-290.
} 
prywatne). Chcąc zachęcić sektor prywatny do wykazania się większą aktywnością gospodarczą, często stosuje się różnego rodzaju ulgi, subsydia, pomoce kredytowe etc. $^{7}$

\section{Struktura dochodów budżetowych}

Dochodami budżetu państwa są środki pieniężne pobierane od podmiotów gospodarczych i gospodarstw domowych przez państwo bądź odrębny organ samorządu terytorialnego zobligowany do tego. Istotą dochodów jest realizacja wydatków, które zapewniają wypełnianie zadań państwowych. Ważnym faktem jest to, iż nie wszystkie środki pobierane przez państwo są dochodami budżetu.

Według ustawy o finansach publicznych (art. 111) z 2009 r. wyróżnić można wachlarz różnego rodzaju środków, które stanowią właśnie dochód. Źródłami dochodów budżetów państwa są: podatki, cła, opłaty administracyjne (por. rysunek 1). Istotne jest, iż dochody ze sprzedaży majątku państwowego nie są traktowane jako dochody budżetu państwa. Wyżej wspomniane dochody służyć mogą finansowaniu powstałego deficytu budżetowego.

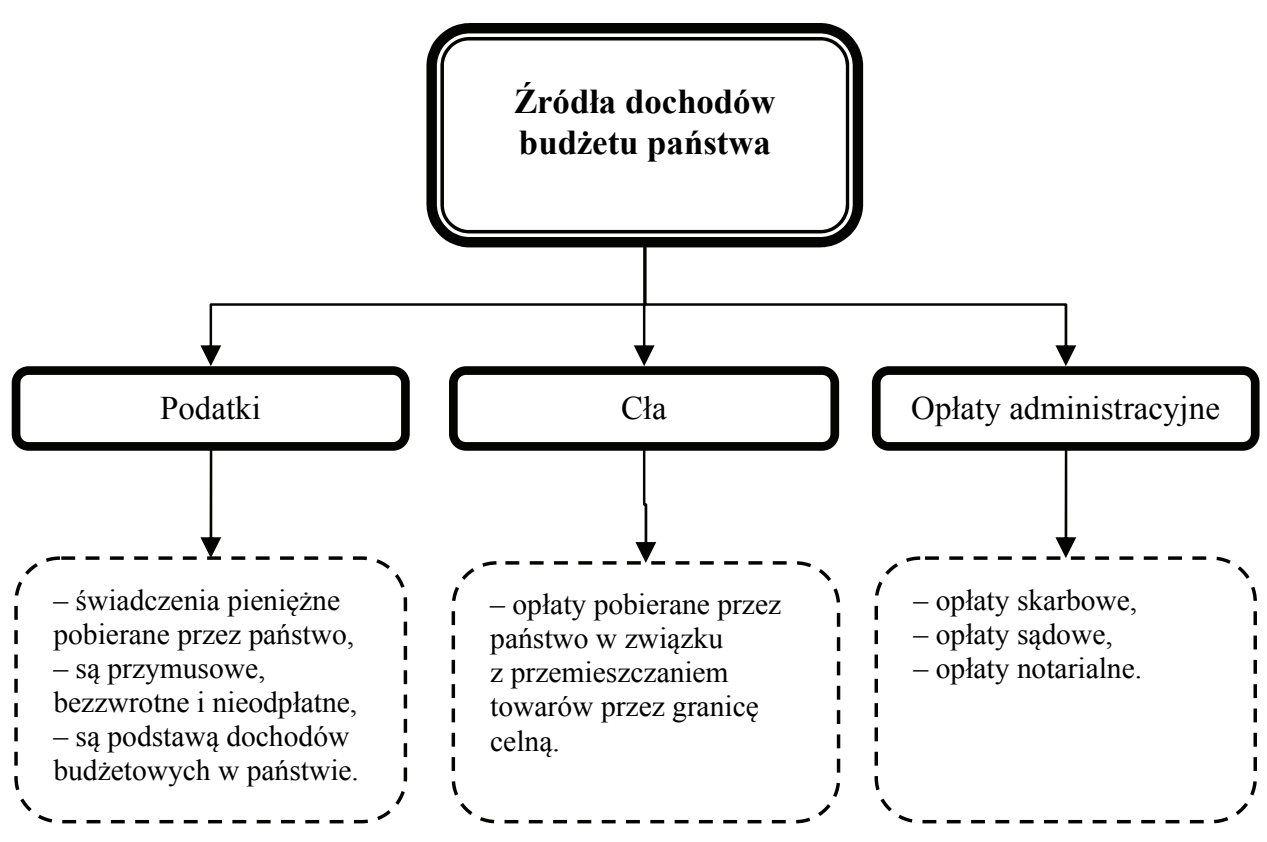

Rysunek 1. Podział źródeł dochodów budżetu państwa

Źródło: opracowanie własne na podstawie: R. Milewski, E. Kwiatkowski (red.), Podstawy ekonomii, Wyd. Nauk. PWN, Warszawa 2008.

${ }^{7}$ Ibidem, s. 283-285. 
Jak wspomniano wcześniej, największy udział w dochodach budżetu państwa stanowią podatki. W roku $2010 \mathrm{w}$ Polsce udział ten kształtował się na poziomie bliskim $89 \%$ (por. rysunek 2). Wyróżniono także środki pochodzące z Unii Europejskiej, wówczas kształtowały się na poziomie 1\%.

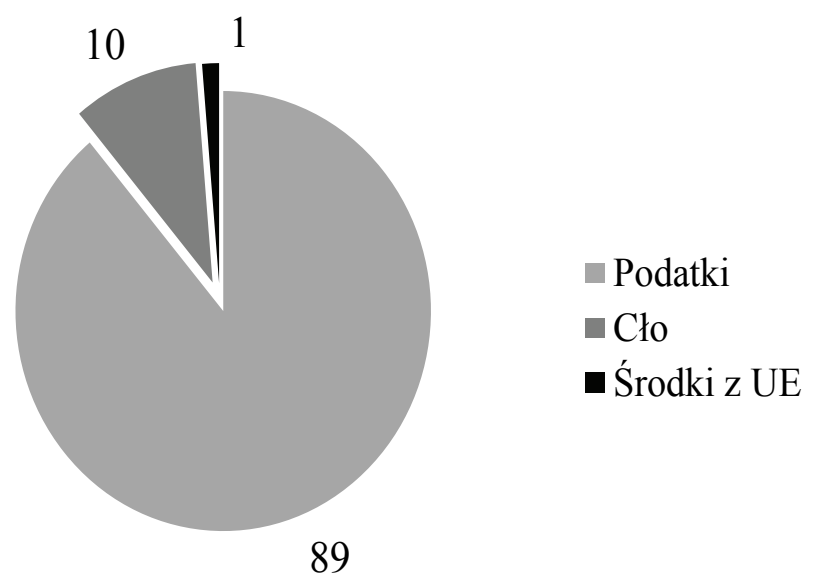

Rysunek 2. Struktura dochodów budżetu w Polsce w roku 2010 (w \%)

Źródło: opracowanie własne na podstawie: Analiza wykonania budżetu państwa i założeń polityki pieniężnej w 2010 roku, NIK, Warszawa 2011, s. 52.

Podatek to klasyczna danina publiczna. Jest jednostronnym (podatki pobierane są i ustalane przez państwo w drodze jednostronnej decyzji, podatnik nie ma wpływu na wysokość ustalonego obciążenia) ustalonym świadczeniem pieniężnym o charakterze przymusowym (obowiązek podatkowy wynika z przepisu prawa podatkowego lub z decyzji administracyjnej organu nakładającego podatek), bezzwrotnym (wpłacona należność podatkowa nie podlega zwrotowi, ponieważ pobierane podatki stanowią dochody publiczne, które $\mathrm{w}$ efekcie przekształcają się w wydatki publiczne), nieodpłatnym (inaczej tzw. nieekwiwalentość, polega na tym, że podmiotowi, który go zapłacił nie przysługuje $\mathrm{z}$ tego tytułu roszczenie wzajemnego świadczenia ze strony państwa czy organizacji samorządowej, podatki nie są pobierane według zasad ekwiwalentności świadczeń, lecz według zasady zdolności podatkowej do ponoszenia ciężarów na rzecz państwa; miarą tej zdolności jest dochód, majątek, konsumpcja) oraz powszechnym (inaczej ogólnym; podatek jest pobierany przez państwo według odrębnych przepisów prawa podatkowego, które określa warunki, wysokość i terminy płatności podatku, każdy podmiot jest zobowiązany płacić podatek w wysokości i terminie określonym w prawie) ${ }^{8}$.

\footnotetext{
${ }^{8}$ M. Podstawska, Finanse, Wyd. Nauk. PWN, Warszawa 2010, s. 220-222.
} 
Za twórcę pierwszych zasad podatkowych uznaje się Adama Smitha. Sformułował on cztery podstawowe kanony podatkowe:

- równomierność obciążenia podatkami - podatki powinny być proporcjonalne do osiąganych dochodów;

- pewność podatku - jednostka ma obowiązek zapłacić podatek, który nie ma charakteru dobrowolnego;

- taniość poboru - pobieranie podatków powinno odbywać się po jak najniższym koszcie oraz jak najmniejszej komplikacji związanej ze ściągalnością;

- dogodność poboru podatku - podatek powinien być pobierany w sposób i w czasie, który jest najdogodniejszy dla podatnika9 .

Można dokonać także podziału podatków na podstawowe grupy ze względu na ich pośredniość. Na tej podstawie wyróżnia się:

- podatki bezpośrednie - bezpośrednio obciążają osiągane przez podatników dochody lub majątek (CIT i PIT);

- podatki pośrednie - nie pozostają w ścisłym związku z sytuacją materialną podatnika, obciążają podatnika w sposób pośredni, przykładowo w momencie zakupu dóbr czy usług (VAT, podatek akcyzowy, podatek od gier) ${ }^{10}$.

Istotny z punktu widzenia przedmiotu opodatkowania wydaje się być podział na podatki dochodowe, przychodowe, majątkowe oraz konsumpcyjne. W przypadku podatków dochodowych przedmiotem opodatkowania jest dochód, rozumiany jako nadwyżka przychodów nad kosztami ich uzyskania (podatek dochodowy od osób fizycznych i podatek dochodowy od osób prawnych). Przy wymiarze podatków przychodowych koszty uzyskania przychodów nie są w ogóle brane pod uwagę, nawiązują jedynie do zewnętrznych znamion świadczących o domniemaniu uzyskania dochodu. Podatki te pobierane są od przychodów osiąganych przez podmioty prowadzące działalność gospodarczą. Podatki majątkowe występują w wielu formach, wymierzane są od wartości majątku podatnika, obciążają całość majątku podatnika, przykładowo podatek od nieruchomości, podatek od środków transportowych, podatek od spadków i darowizn, podatek od czynności cywilnoprawnych, podatek rolny, podatek leśny, podatek od nieruchomości. Z kolei źródłem podatków konsumpcyjnych jest dochód wydatkowany, zaś kwota podatku zostaje umieszczona w cenie dóbr i usług (VAT, akcyza). Podatki te obciążają dochód podatnika w momencie wydatkowania, na przykład podatek od towarów i usług, podatek akcyzowy, podatek od gier ${ }^{11}$.

${ }^{9}$ W. Ziółkowska, Finanse publiczne. Teoria i zastosowanie, Wyd. Wyższej Szkoły Bankowej, Poznań 2005, s. 88-96.

${ }^{10}$ Ibidem.

${ }^{11}$ Ibidem. 


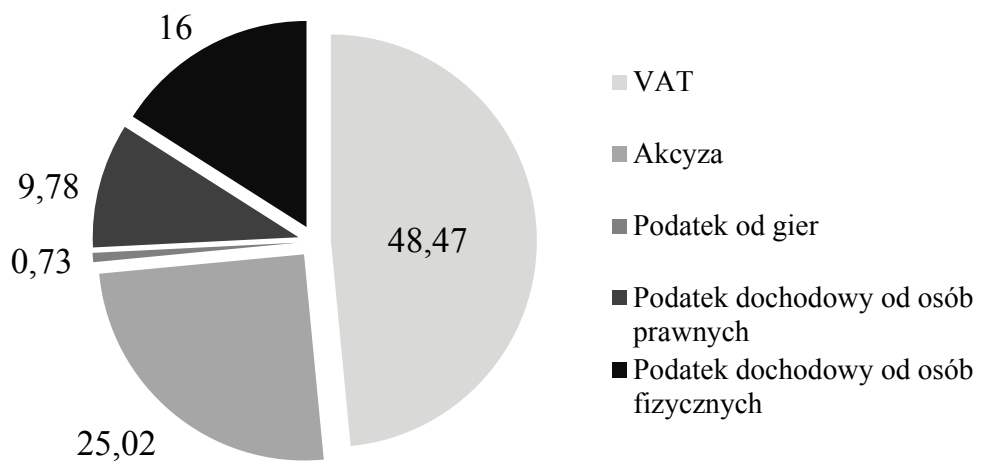

Rysunek 3. Struktura dochodów podatkowych w Polsce według rodzajów w roku 2010 (w \%)

Źródło: opracowanie własne na podstawie: Analiza wykonania budżetu państwa i założeń polityki pieniężnej w 2010 roku, NIK, Warszawa 2011, s. 53.

Na rysunku 3 ukazano strukturę dochodów podatkowych według ich rodzajów w Polsce w 2010 r. Należy wskazać, że najistotniejsze znaczenie wówczas miały podatki pośrednie, takie jak VAT i akcyza (łącznie stanowiły blisko 73,49\%).

Ważnym elementem klasyfikacji podatków jest wskazanie podmiotu. Biorąc pod uwagę to kryterium wskazać można:

- podmiot czynny - związek publicznoprawny (władze państwa, lokalne) uprawniony do nakładania podatków;

- podmiot bierny - podatnicy, płatnicy oraz inkasenci ${ }^{12}$.

Obciążenia podatkowe mogą być naliczane w różny sposób, można wyróżnić trzy rodzaje skal:

- podatki proporcjonalne - wszyscy podatnicy płacą ten sam procent swoich dochodów, obowiązuje jedna stopa podatkowa;

- podatki progresywne - osoby uzyskujące wyższe dochody obciążone są wyższą stopą podatkową;

- podatki degresywne - wraz ze wzrostem dochodu nakładane są coraz mniejsze procentowe stawki podatkowe ${ }^{13}$.

\section{Istota wydatków budżetu państwa}

Sprawne funkcjonowanie państwa zapewnia odpowiednia struktura wydatków budżetowych. Można wyróżnić następujące grupy wydatków:

1. Tradycyjne funkcje państwa - obrona narodowa, administracja i wymiar sprawiedliwości.

\footnotetext{
${ }^{12}$ Ibidem.

${ }^{13}$ Ibidem.
} 
2. Realizacja celów społecznych - oświata, kultura, zdrowie, świadczenia socjalne etc.

3. Interwencjonizm państwowy - inwestycje państwowe i inwestycje strukturalne $\mathrm{e}^{14}$.

Ustalanie wydatków budżetowych powinno odbywać się w sposób celowy i oszczędny, lecz również tak, aby zapewnić terminowość wykonania wszystkich zadań. Wydatki według ustawy z dnia 27 sierpnia 2009 r. o finansach publicznych (Dz. U. z 2009 r., nr 157, poz. 1240, art. 112) można podzielić na:

- dotacje i subwencje, które obejmują finansowanie lub dofinansowanie realizacji zadań publicznych;

- świadczenia na rzecz osób fizycznych, nie są one wynagrodzeniem za świadczoną pracę, np. emerytury, renty dla osób niepełnosprawnych, zasiłki dla bezrobotnych;

- wydatki bieżące jednostek budżetowych, które obejmują wynagrodzenia i uposażenia osób zatrudnionych w jednostkach budżetowych oraz koszt utrzymania tych jednostek;

- wydatki majątkowe, które obejmują wydatki inwestycyjne państwowych jednostek budżetowych oraz dotacje celowe pokrywające koszty inwestycji prowadzonych przez inne jednostki;

- wydatki na obsługę długu Skarbu Państwa, które obejmują wydatki budżetu państwa związane $\mathrm{z}$ oprocentowaniem od skarbowych papierów wartościowych oraz zaciągniętych kredytów i pożyczek, a także wypłaty związane z udzielonymi przez Skarb Państwa poręczeniami i gwarancjami;

- wydatki na realizację programów pomocowych, finansowanych z udziałem środków Unii Europejskiej, które obejmują udział we wpływach z ceł, opłat rolnych i cukrowych, środki z podatku od towarów i usług, zgodnie z metodologią wynikającą z przepisów Unii Europejskiej oraz środki obliczone na podstawie wartości rocznego produktu krajowego brutto.

Tabela 1. Wydatki budżetu państwa w ujęciu zadaniowym na rok 2012

\begin{tabular}{|c|l|c|c|}
\hline \multicolumn{2}{|c|}{ Funkcja } & $\begin{array}{c}\text { Lączna kwota } \\
\text { planowana }\end{array}$ & $\begin{array}{c}\text { W tym środki } \\
\text { z budżetu } \\
\text { europejskiego }\end{array}$ \\
\hline \multicolumn{1}{|c|}{1} & 2 & 3 \\
\hline F1 & Sprawne państwo & 1363,4 & 10,6 \\
\hline F2 & Bezpieczeństwo wewn. i porządek publiczny & 15806,2 & 52,3 \\
\hline F3 & Edukacja, wychowanie i opieka & 53465,1 & 1020,5 \\
\hline F4 & Zarządzanie finansami państwa & 134346,0 & 39986,1 \\
\hline
\end{tabular}

${ }^{14}$ R. Milewski, E. Kwiatkowski (red.), Podstawy..., s. 322. 
Tabela 1 (cd.)

\begin{tabular}{|r|l|r|r|}
\hline \multicolumn{2}{|c|}{1} & \multicolumn{1}{c|}{3} & \multicolumn{1}{c|}{4} \\
\hline F5 & Ochrona praw i interesów Skarbu Państwa & 186,3 & 0,0 \\
\hline F6 & Polityka gospodarcza kraju & 5173,2 & 2354,8 \\
\hline F7 & Gospodarka przestrzenna i budownictwo & 1851,9 & 84,4 \\
\hline F8 & Kultura fizyczna & 643,8 & 0,0 \\
\hline F9 & Kultura i dziedzictwo narodowe & 1730,2 & 0,0 \\
\hline F10 & Nauka polska & 6468,3 & 1311,4 \\
\hline F11 & Bezpieczeństwo zewn. i nienaruszalność granic & 22326,7 & 0,0 \\
\hline F12 & Środowisko & 3077,8 & 2463,3 \\
\hline F13 & Zabezpieczenie społeczne i wspieranie rodziny & 90162,0 & 9,0 \\
\hline F14 & Rynek pracy & 1523,4 & 452,1 \\
\hline F15 & Polityka zagraniczna & 1566,4 & 0,0 \\
\hline F16 & Sprawy obywatelskie & 1926,8 & 529,3 \\
\hline F17 & Kształtowanie rozwoju regionalnego kraju & 16303,2 & 13720,0 \\
\hline F18 & Sprawiedliwość & 9079,8 & 18,7 \\
\hline F19 & Infrastruktura transportowa & 11804,8 & 4168,7 \\
\hline F20 & Zdrowie & 7067,9 & 228,5 \\
\hline F21 & Polityka rolna i rybacka & 16671,9 & 10644,8 \\
\hline F22 & Planowanie strategiczne i obsługa techniczna & 3311,4 & 49,5 \\
\hline
\end{tabular}

Źródło: Ustawa budżetowa na rok 2012 uzasadnienie t. II, Omówienie - wydatki budżetowe w układzie zadaniowym, Rada Ministrów, Budżet Zadaniowy, Warszawa 2011, rozdz. II.

$\mathrm{Z}$ danych zawartych $\mathrm{w}$ tabeli 1można wnioskować, jak istotną pozycję w wydatkach budżetowych stanowią środki europejskie. Niektóre funkcje, takie jak ochrona praw i interesów skarbu państwa, kultura fizyczna, kultura i dziedzictwo narodowe, bezpieczeństwo zewnętrzne i nienaruszalność granic oraz polityka zagraniczna nie są wspierane przez te środki. Natomiast funkcja kształtowania rozwoju regionalnego kraju jest pokryta aż w $85 \%$ z tych środków. Podobny, bardzo wysoki udział środków europejskich w łącznej kwocie planowania na rok 2012 możemy zaobserwować w funkcjach: środowisko (ponad 80\%) i sprawne państwo (niespełna 78\%). Aby móc lepiej uświadomić sobie skalę wydatków na poszczególne funkcje, skonstruowany został wykres wydatków budżetowych. 


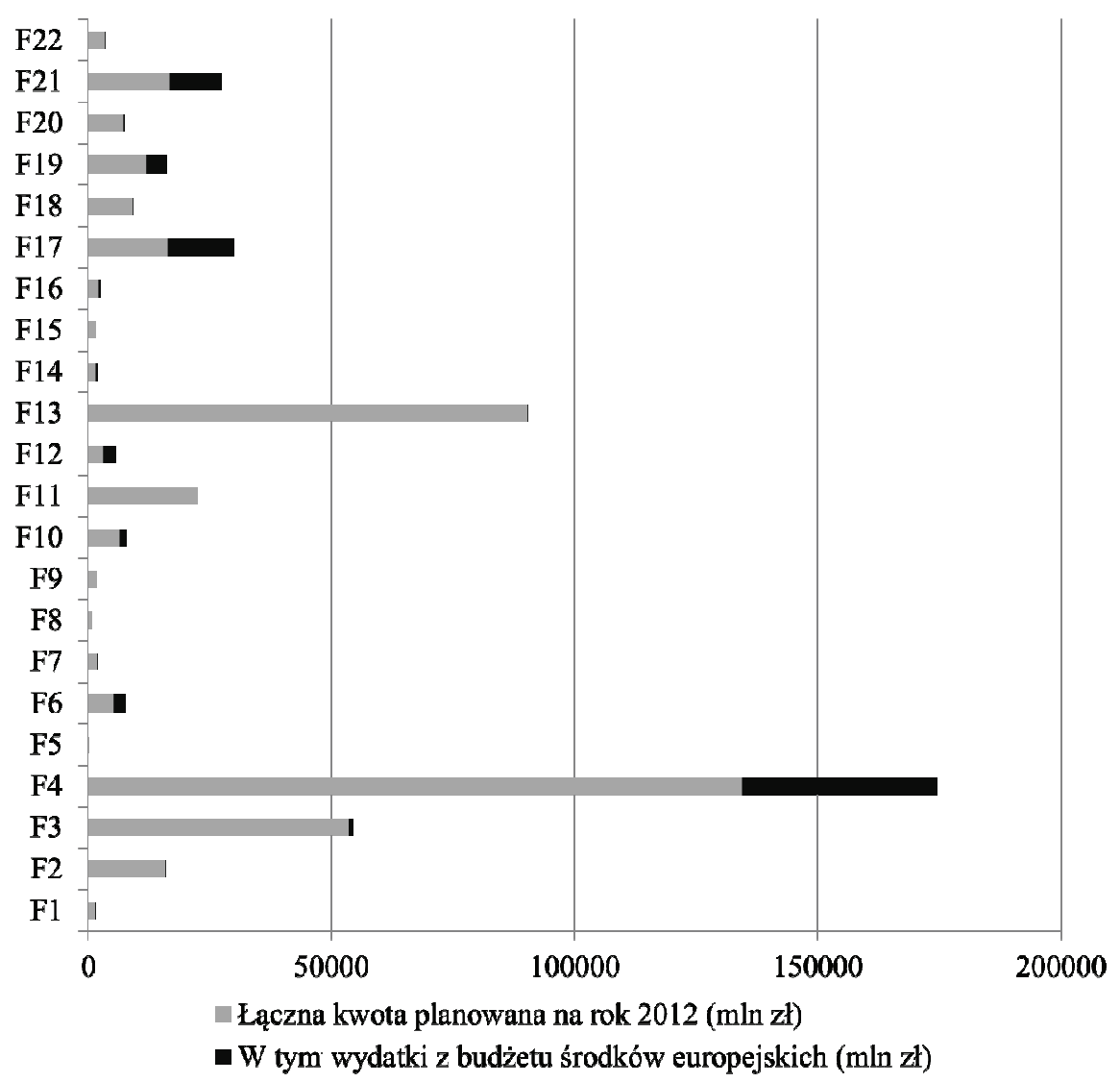

Rysunek 4. Wykres budżetowych wydatków zadaniowych na rok 2012

Źródło: Ustawa budżetowa na rok 2012 uzasadnienie, tom 2, Omówienie. Wydatki budżetowe w układzie zadaniowym, Budżet Zadaniowy, Warszawa 2011, rozdz. II.

Analizując dane na rysunku 4, zarządzanie finansami państwa (F4) wyraźnie przoduje w wydatkach budżetowych w Polsce w roku 2012. Dość duży jest udział $\mathrm{w}$ tej funkcji dotacji pochodzących z budżetu środków europejskich. Drugą pod względem wysokości wydatków budżetowych jest funkcja zabezpieczenia społecznego i wspierania rodziny (F13), w której udział środków europejskich jest jednak niewielki. Podobnie jest $\mathrm{z}$ trzecią funkcją pod względem wielkości wydatków budżetowych: edukacją, wychowaniem i opieką (F3). Kształtowanie rozwoju regionalnego kraju (F17) oraz polityka rolna i rybacka (F21) to kolejne dwie funkcje pod względem wielkości przeznaczonych wydatków budżetowych. Najmniej wydatków budżetowych przekazywanych jest na ochronę praw i interesów Skarbu Państwa (F5) oraz kulturę fizyczną (F8) - te dwie funkcje nie są wspierane z budżetu środków europejskich. 


\section{Model wydatków budżetowych w polskich województwach}

Wpływ na rozwój społeczno-gospodarczy wyrażony poprzez wartość brutto środków trwałych (zmienna ta odzwierciedla rozwój społeczno-gospodarczy danego obszaru) w gospodarce narodowej ogółem zbadano poprzez wydatki budżetowe na wszystkie funkcje zadaniowe w poszczególnych województwach w Polsce w latach 2008-2010 ${ }^{15}$. Do analizy tego zjawiska wykorzystano modele panelowe z dekompozycją wyrazu wolnego i dekompozycją składnika losowe$\mathrm{go}^{16}$. Do zweryfikowania, który model najlepiej zastosować $\mathrm{w}$ tym przypadku po przeprowadzeniu estymacji posłużono się testami: Chowa (F), mnożnika Lagrange'a (LM) oraz Hausmana.

Tabela 2. Test Chowa (F)

\begin{tabular}{|lcrcrrcc|}
\hline & Wskaźnik wiarygodności testów & \multicolumn{3}{c|}{ Test F } \\
(2) vs (1) & Chi-kwadrat & d.f. & Praw. & \multicolumn{1}{c|}{ F } & num. & denom. & Prob. value \\
(3) vs (1) & 233,013 & 15 & 0,0000 & 271,590 & 15 & 32 & 0,0000 \\
(4) vs (1) & 147,059 & 8 & 0,0000 & 99,486 & 8 & 39 & 0,0000 \\
(4) vs (2) & 391,709 & 23 & 0,0000 & 3651,421 & 23 & 24 & 0,0000 \\
(4) vs (3) & 158,696 & 8 & 0,0000 & 78,841 & 8 & 24 & 0,0000 \\
\hline
\end{tabular}

Źródło: obliczenia własne wykonane w programie LIMDEP (dotyczy tabel 2-5).

Wartość testu Chowa wynosi 260,013. Przy takiej wartości statystyki F empiryczny poziom prawdopodobieństwa jest mniejszy od 0,05 . Na tej podstawie można stwierdzić, że model z efektami grupowymi (FEM) jest lepszym modelem niż model podstawowy. Wyrazy wolne dla grup różnią się w sposób istotny, dlatego też wprowadzenie dekompozycji wyrazu wolnego było uzasadnione z punktu widzenia sensu ekonomicznego.

${ }^{15} \mathrm{~W}$ badaniu uwzględniono wydatki na: W1 - Rolnictwo i łowiectwo, W2 - Przetwórstwo przemysłowe, W3 - Wytwarzanie i zaopatrywanie w energię elektryczną, gaz i wodę, W4 - Transport i łączność, W5 - Turystykę, W6 - Gospodarkę mieszkaniową, W7 - Działalność usługową, W8 - Naukę, W9 - Administrację publiczną, W10 - Obsługę długu publicznego, W11 - Różne rozliczenia, W12 - Oświatę i wychowanie, W13 - Ochronę zdrowia, W14 - Pomoc społeczną, W15 - Pozostałe zadania w zakresie polityki społecznej, W16 - Edukacyjną opiekę wychowawczą, W17 - Gospodarkę komunalną i ochronę środowiska, W18 - Kulturę i ochronę dziedzictwa narodowego, W19 - Ogrody botaniczne i zoologiczne oraz naturalne obszary i obiekty chronionej przyrody, W20 - Kulturę fizyczną i sport (wszystkie dane pochodzą z Banku Danych Lokalnych na: www.stat.gov.pl, stan na dzień 12.02.2012).

16 Modele skonstruowano na podstawie wzorów w: B. Dańska-Borsiak, Przestrzenno-czasowe modelowanie zmian $w$ działalności produkcyjnej $w$ Polsce, zastosowanie modeli panelowych, t. 1, [w:] B. Suchecki (red.), Dane panelowe $i$ modele wielowymiarowe $w$ badaniach ekonomicznych, Absolwent, Łódź 2000, s. 36-42. 
Tabela 3. Test mnożnika Lagrange'a (LM) i test Hausmana

Test mnożnika Lagrange'a (LM) vs. Model podstawowy. $=.00$

$(1 \mathrm{df}$, prob value $=.957006)$

(Wysokie wartości LM faworyzują model FEM)

FEM vs. REM $($ Test Hausmana $)=283.83$

( $8 \mathrm{df}$, prob value $=.000000$ )

(Wysokie (niskie) wartości testu H faworyzują FEM (REM).)

Używając testu mnożnika Lagrange'a (LM) można stwierdzić czy model z dekompozycją składnika losowego jest lepszy od modelu podstawowego. Test LM przyjmuje wartość zero, a empiryczny poziom prawdopodobieństwa przy tym teście jest znacznie wyższy niż 0,05 co świadczy o tym, że model REM jest gorszym modelem niż model podstawowy. Na tej podstawie można stwierdzić, że w danym badaniu wprowadzenie dekompozycji składnika losowego nie jest konieczne.

Do zweryfikowania efektywności modeli z dekompozycją wyrazu wolnego FEM i dekompozycją składnika losowego REM wykorzystano test Hausmana. Wysokie wartości tego testu $(283,83)$ i empiryczny poziom prawdopodobieństwa mniejszy od 0,05 przemawia na korzyść modelu FEM. Dlatego też badane zjawisko wpływu wydatków budżetowych na wartość dodaną środków trwałych w gospodarce narodowej zostanie opisane na podstawie modelu $\mathrm{z}$ dekompozycją wyrazu wolnego, który uwzględnia specyficzne efekty dla wszystkich 16 polskich województw.

Wyniki estymacji modelu FEM po usunięciu zmiennych nieistotnych pokazały, że wszystkie wydatki budżetowe mają pozytywny wpływ na wartość brutto środków trwałych we wszystkich 16 województwach w Polsce (tabela 4).

Tabela 4. Wyniki estymacji modelu FEM

\begin{tabular}{|cccccc|}
\hline Zmienna & Parametr & Błąd standardowy & Wsk. t & P $[|\mathrm{T}|>\mathrm{t}]$ & Śr. z X \\
\hline W1 & 123,3446903 & 25,225322 & 4,890 & 0,0000 & 56,362334 \\
W4 & 19,65274538 & 7,8778695 & 2,495 & 0,0168 & 361,47790 \\
W6 & 33,05517400 & 13,787790 & 2,379 & 0,0213 & 10,864802 \\
W8 & $-613,8641601$ & 160,26315 & $-3,830$ & 0,0004 & 1,3456282 \\
W9 & 123,5820990 & 61,489035 & 2,010 & 0,0512 & 75,129228 \\
W11 & 314,2756480 & 27,348573 & 11,491 & 0,0000 & 53,778692 \\
W17 & 91,83419730 & 45,541499 & 2,016 & 0,0505 & 7,9329541 \\
W19 & 1721,847059 & 261,79132 & 6,577 & 0,0000 & 1,6546754 \\
\hline
\end{tabular}


Wartości parametrów stojących przy zmiennych objaśniających są większe od zera, dlatego też można stwierdzić, że wzrost którejkolwiek ze zmiennych objaśniających (w przedmiocie badania wydatków budżetowych na poszczególne funkcje zadaniowe) spowoduje wzrost zmiennej objaśnianej (w przedmiocie badania wartość środków trwałych brutto). Wyjątkiem była zmienna określająca wydatki na naukę (W8). Parametr przy tej zmiennej był ujemny, co świadczy o tym, że im większe wydatki na naukę tym gorsza wartość brutto środków trwałych. Jest to oczywiście sprzeczne z punktu widzenia sensu ekonomicznego. Taką sytuację można uzasadnić jednak w ten sposób, że nauka jest finansowana na poziomie centralnym, a nie w poszczególnych województwach.

Tabela 5. Dekompozycja wyrazu wolnego

\begin{tabular}{|lccc|}
\hline \multicolumn{1}{|c}{ Województwo } & Wyraz wolny & Błąd standardowy & Wsk. t \\
\hline Lubuskie & 41407,94966 & 2584,57611 & 16,02118 \\
Świętokrzyskie & 41608,84555 & 3053,17235 & 13,62807 \\
Opolskie & 48794,89005 & 2633,12864 & 18,53115 \\
Podlaskie & 49742,48321 & 2738,95533 & 18,16112 \\
Warmińsko-mazurskie & 51479,01926 & 3282,59055 & 15,68244 \\
Podkarpackie & 75466,35905 & 3679,15176 & 20,56219 \\
Kujawsko-pomorskie & 79514,98815 & 3663,37477 & 21,70539 \\
Zachodniopomorskie & 80501,96209 & 3452,24886 & 23,31870 \\
Lubelskie & 82680,83998 & 3327,24851 & 24,84961 \\
Pomorskie & 106139,48427 & 3782,46231 & 28,06095 \\
Lódzkie & 116899,48715 & 4484,45326 & 26,06772 \\
Małopolskie & 138525,65711 & 4402,45217 & 31,46557 \\
Dolnośląskie & 152312,32379 & 5096,41183 & 29,88619 \\
Wielkopolskie & 179711,81107 & 4637,76217 & 38,74968 \\
Mazowieckie & 202882,76234 & 24029,08427 & 8,44322 \\
Śląskie & 233772,70418 & 5231,36789 & 44,68673 \\
\hline
\end{tabular}

Dekompozycja wyrazu wolnego pokazała, że w poszczególnych województwach wydatki budżetowe mają różny wpływ na badane zjawisko. Wszystkie wyrazy wolne (dla każdego z województw) są istotne statystycznie na podstawie statystyki $t$-Studenta, dlatego można je interpretować. Skonstruowano mapę (por. rysunek 5), aby lepiej zaprezentować zależność przestrzenną siły wpływu wydatków budżetowych na rozwój społeczno-gospodarczy w danych województwach. 


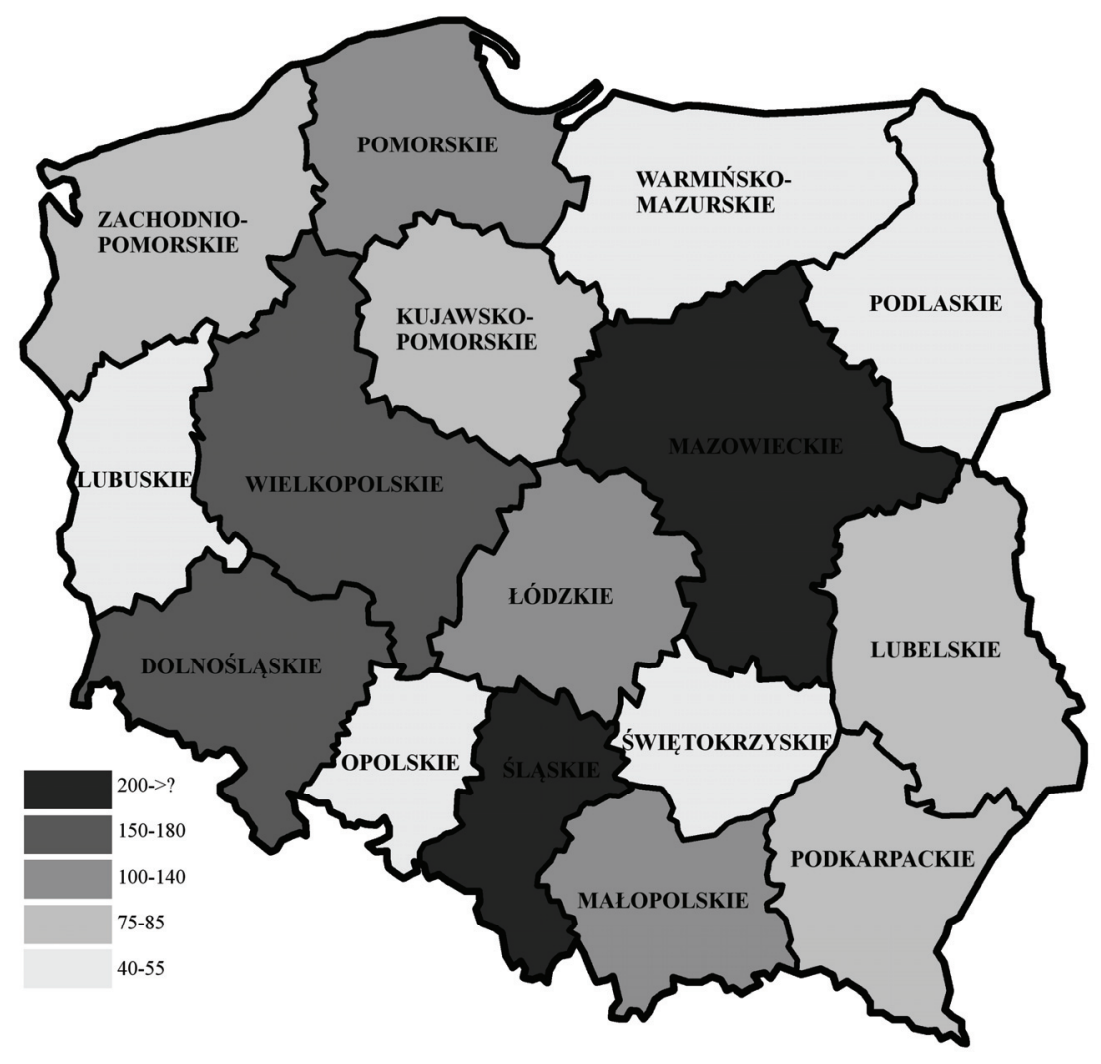

Rysunek 5. Mapa dekompozycji wyrazu wolnego 16 województw w Polsce Źródło: opracowanie własne.

\section{Zakończenie}

Polityka budżetowa prowadzona przez dane państwo jest bardzo ważnym elementem sprawnego i efektywnego funkcjonowania całej jego gospodarki. Zatem zamierzeniem każdej jednostki terytorialnej są takie przemyślane działania, które mogą się przyczynić do wzrostu społeczno-gospodarczego, a w konsekwencji do wzrostu konkurencyjności i innowacyjności poszczególnych regionów, jak i całego kraju.

Przeprowadzone badanie pozwoliło na klasyfikację terytorialną 16 polskich województw pod względem wielkości wyrazu wolnego, dla panelowego modelu uwzględniającego specyficzne efekty dla wszystkich analizowanych obszarów. Zmienna objaśniana wyrażona poprzez wartość środków trwałych brutto jest w przedmiocie badania odzwierciedleniem wzrostu społeczno-gospodarczego w danym województwie. Na podstawie wyników, regiony zostały podzielone na 
5 grup. Największy wpływ wydatków budżetowych na wzrost społeczno-gospodarczy obserwowany jest w województwach: śląskim i mazowieckim (grupa 1). Nieco mniejszy wpływ wydatków budżetowych zanotowano w grupie 2 , do której przyporządkowano województwa: dolnośląskie i wielkopolskie. Kolejną grupę stanowią województwa: łódzkie, małopolskie i pomorskie. Czteroelementową grupę utworzyły województwa: kujawsko-pomorskie, lubelskie, podkarpackie i zachodniopomorskie. Najliczniejszą, pięcioelementową grupą była ta, w której wpływ wydatków budżetowych na wzrost społeczno-gospodarczy był najniższy. W skład tej grupy wchodziło 5 województw: lubuskie, świętokrzyskie, opolskie, podlaskie, warmińsko-mazurskie. Należy zwrócić uwagę, że dwie najsłabsze grupy zgromadziły aż 9 województw, co może świadczyć o dość dużej dysproporcji rozwojowej. W badaniu najgorzej wypadła cała granica wschodnia oraz północno-wschodnia część kraju, gdzie struktura wydatków budżetowych samorządów lokalnych nadal wymaga udoskonalenia.

Nie ma wątpliwości, że wydatki budżetowe pozytywnie wpływają na wzrost społeczno-gospodarczy. Problem tkwi jednak w tym jak dopasować strukturę wydatków, aby ten wzrost był jak najbardziej efektywny. Na tym etapie pojawia się także dylemat, na jakim poziomie ustalić deficyt budżetowy, aby koszt jego obsługi był niższy niż pożytek płynący ze zwiększenia wydatków budżetowych. Trzeba bowiem pamiętać, że w przy niewielkich rozmiarach deficyt budżetowy może mieć pozytywny wpływ na tempo rozwoju gospodarczego (jest to zauważalne szczególnie w okresie recesji, kiedy to większy interwencjonizm państwowy jest konieczny). Natomiast gdy poziom deficytu przekroczy pewną bezpieczną granicę (szacowaną przez wielu ekonomistów na poziomie 5\% produktu narodowego brutto) może to doprowadzić do poważnych zaburzeń zachodzących w gospodarce, w tym wzrostu inflacji.

\section{Literatura}

Analiza wykonania budżetu państwa i założeń polityki pieniężnej w 2010 roku, NIK, Warszawa 2011.

Borodo A., Brzeziński B., Drgas E., Głuchowski J., Jezierski J., Zarys prawa finansowego, Wyd. UMK, Torun 1989.

Borodo A., Polskie prawo finansowe. Zarys ogólny, Dom Organizatora, Torun 2003.

Brzeziński B., Dębowska-Romanowska T., Kalinowski M., Wójtowicz W., Prawo finansowe, C.H. BECK, Warszawa 2000.

Milewski R. , Kwiatkowski E. (red.), Podstawy ekonomii, Wyd. Nau. PWN, Warszawa 2008.

Podstawska M., Finanse, Wyd. Nauk. PWN, Warszawa 2010.

Suchecki B. (red.), Dane panelowe $i$ modele wielowymiarowe $w$ badaniach ekonomicznych, Absolwent, Łódź 2000.

Ustawa z dnia 27 sierpnia 2009 r. o finansach publicznych, Dz. U. z 2009 r., nr 157, poz. 1240.

Winiarski B. (red.), Polityka budżetowa, Wyd. Nauk. PWN, Warszawa 2006.

Ziółkowska W., Finanse publiczne. Teoria i zastosowanie, Wyd. Wyższej Szkoły Bankowej, Poznań 2005. 


\section{Streszczenie}

Artykuł ma na celu przybliżenie teoretycznych aspektów funkcjonowania budżetu Polski. Zaprezentowana teoria jest zatem podstawą do badania empirycznego, prezentującego wpływ wydatków budżetowych samorządów terytorialnych na rozwój społecznogospodarczy wszystkich polskich województw. Jako narzędzie badawcze zastosowano panelowe modele $z$ dekompozycją wyrazu wolnego (FEM) i dekompozycją składnika losowego (REM) dla dwudziestu zmiennych egzogenicznych na przestrzeni 3 lat. Zakłada się, że siła wpływu wydatków budżetowych na wartość brutto środków trwałych w badanych obszarach istotnie się różni.

\section{Summary}

\section{LOCAL GOVERNMENTS BUDGET EXPENDITURE AS A POLISH PROVINCES DETERMINANT OF SOCIO-ECONOMIC DEVELOPMENT}

Article aims to explain the theoretical aspects of the functioning and structure of the Polish budget. The presented theory is thus the basis for the empirical study, presenting the impact of local governments budgetary expenditure on socio-economic development of all the Polish provinces. As a research tool were used panel models with the decomposition of the intercept (FEM) and the decomposition of the random component (REM) for twenty exogenous variables in the space of three years. It is assumed that the force of the impact of expenditure on gross value of fixed assets in the areas examined is significantly different. 